\title{
PROGRAM LIBRARY USER EDUCATION TERHADAP OPTIMALISASI LAYANAN PERPUSTAKAAN STMIK STIKOM INDONESIA
}

\author{
Sri Widiastutik, ${ }^{1}$ Ni Nengah Dita Ardriani, ${ }^{2}$ \\ STMIK STIKOM Indonesia, Jl Tukad Pakerisan no 97 Panjer, Denpasar Selatan, \\ Denpasar, Bali, Indonesia, 80225 \\ Sri Widiastutik-Koresponden: wid.widiast@gmail.com
}

\begin{abstract}
Abstrak
Kunci sukses sebuah perpustakaan adalah keharmonisan hubungan antara pemustaka dengan pustakawan dalam berinteraksi. Terjalinnya interaksi antara kedua pihak sebagai pondasi utama tercapainya tujuan layanan sebuah perpustakaan, tersampaikannya layanan pustakawan selaras dengan terakomodirnya kebutuhan pemustaka. Sejak semula pustakawan dituntut untuk berorientasi terhadap kebutuhan pemustaka, namun dengan semakin pesat ilmu pengetahuan dan makin canggihnya teknologi, pemustaka pun mempunyai andil besar untuk memposisikan dirinya tidak ketinggalan informasi. Dewasa ini, pemustaka seolah dituntut sadar diri, tahu diri terhadap perkembangan yang terjadi jika tidak ingin tertinggal informasi. Dengan kata lain, seiring tingkat kebutuhannya terhadap informasi yang sangat tinggi, pemustaka pun dituntut untuk berorientasi pada informasi, yaitu beorientasi pada perpustakaan sebagai wadah (penampung) informasi, maupun pustakawan sebagai penyalur layanan informasi.Guna mengantisipasi ketidakharmonisan tersebut, pada penelitian ini diusulkan sebuah program Library User Education (LUE) - Malley (dalam IBLims, 2015) bagi pengguna (pemustaka) perpustakaan STIKI sebagai satu faktor yang menjembatani misinformation pemustaka terhadap tata cara maupun kebijakan perpustakaan. Diharapkan perpustakaan STIKI mampu memberikan layanan perpustakaan sebaik mungkin baik sumber daya perpustakaan, layanan maupun fasilitas. Begitu pula pemustaka diharapkan mampu mendapatkan tutorial (pengajaran), diberi pemahaman dan kesempatan untuk mengenal perpustakaan lebih dekat, sehingga pemustaka bisa memanfaatkan sumber-sumber informasi dan layanan perpustakaan secara optimal.
\end{abstract}

Key words: pemustaka, pustakawan, layanan, Library User Education

\section{LATAR BELAKANG}

Perpustakaan merupakan fasilitas pendukung utama dalam sebuah lembaga pendidikan perguruan tinggi. Perpustakaan dengan segala fasilitas dan layanan yang tersedia tentunya akan dimanfaatkan secara optimal apabila pemustakanya mampu menggunakan dan memanfaatkannya secara optimal pula. Kemampuan pemustaka dalam memanfaatkan perpustakaan merupakan dasar yang amat penting dalam mencapai keberhasilan pendidikan. Namun demikian tidak dapat dipungkiri bahwa banyak pemustaka di perguruan tinggi yang be- lum secara optimal memanfaatkan perpustakaan sebagai sumber belajar. Demikian pula dengan perpustakaan STIKI mempunyai peran yang sangat besar untuk mampu memperkenalkan perpustakaan melalui program pelatihan/pendidikan bagi pengguna dalam rangka memasyarakatkan kebijakan-kebijakan perpustakaan secara optimal bagi pemustakanya, terutama mahasiswa sebagai mayoritas pengguna perpustakaan STIKI.

Pendidikan pengguna perpustakaan atau dikenal sebagai Library User Education (LUE), merupakan satu langkah awal yang perlu diterapkan terhadap 
pengguna terutama informasi vital tentang perpustakaan hingga manfaat perpustakaan. Dengan adanya LUE tersebut diharapkan mahasiswa lebih mengenal, mengetahui manfaat perpus secara optimal, bahkan turut menjaga kenyamanan belajar di perpustakaan.

Penelitian ini tidak sekedar untuk meningkatkan kecintaan terhadap perpustakaan, namun lebih pada bagaimana mahasiswa STIKI khususnya mampu mengoptimalkan peran perpustakaan, baik melalui proses tutoring, pelatihan maupun sosialisasi tentang tata cara dan tata tertib perpustakaan. Terjalinnya komunikasi antara pustakawan dengan pemustaka akan semakin menggali budaya minat baca sebagai sebuah wujud nyata kesadaran bagi masyarakat untuk selalu ingin mencari sumber informasi terbaru yang diperlukan.

Dengan demikian penelitian ini mengusulkan program edukasi "Library User Education" bagi seluruh pengguna perpustakaan STIKI. Diharapkan mahasiswa sebagai pemustaka akan lebih mudah mencari sumber-sumber literatur, tidak enggan berkunjung ke perpustakaan, lebih maksimal merasakan manfaat perpustakaan, lebih mandiri dan menjadi sumber daya yang berwawasan.

Berdasarkan latar belakang di atas, maka rumusan masalah dalam penelitian ini adalah:

1. Apakah mahasiswa dapat mengunakan perpustakaan secara efektif dan efisien?

2. Apakah yang harus dilakukan untuk meminimalisir kebingungan pengguna layanan perpustakaan?

3. Bagaimana strategi untuk menumbuhkan rasa peduli, rasa memiliki, dan menanamkan "sikap butuh" mahasiswa terhadap perpustakaan STIKI Indonesia?

Luaran penelitian ini akan dipublikasikan untuk bisa bermanfaat bagi masyarakat luas, antara lain :

1. Melakukan Pengenalan kegiatan pendidikan pemustaka yang disatukan dalam sosialisasi materi mengenai pentingnya perpustakaan, dan memberikan informasi secara langsung (direct welcome service), serta demonstrasi tata cara di perpustakaan.

2. Dipublikasikan dalam Jurnal Ilmiah Pustaka
ber-ISSN.

3. Sebagai sarana sosialisasi dan dukungan terhadap program pemerintah tentang transformasi keberadaan perpustakaan berdasarkan kebutuhan masyarakat, kepentingan dan tuntutan jaman dalam UU no 432007 dan Kemendiknas 25 tahun 2008.

4. Menyokong budaya gemar baca dengan rencana agenda "tiada hari tanpa baca" sebagai upaya dukungan terhadap pemerintah yang telah ditetapkan bulan September sebagai bulan gemar baca dan hari kunjung perpustakaan.

\section{TINJAUAN PUSTAKA}

Pengertian Pendidikan Pemustaka atau Library User Education (LUE) seperti dikemukakan oleh beberapa ahli berikut ini.

Menurut Flemming (dalam Muflihin, 2014) dalam bukunya berjudul "User Education in Academic Libraries" bahwa User education adalah berbagai jenis program tentang pengarahan, pendidikan, dan eksplorasi yang disediakan perpustakaan kepada pengguna untuk menjadikan mereka lebih efektif, efisien, dan mandiri dalam penggunaan sumber-sumber informasi serta pemberdayaannya dan pelayanan informasi yang telah disediakan oleh perpustakaan untuk diakses oleh para pengguna”.

Mews Hazel "instruction given to readers to help them make the best use of a library" (pendidikan pemustaka adalah instruksi yang diberikan kepada pemakai agar mereka dapat menggunakan perpustakaan dengan baik. Malley "a process whereby the library user is firstly made aware of the extend and number of the libraries resources, of its services and of the information sources available to him or her, and secondly taught how to use these resources, services and sources" (pendidikan Pemustaka adalah suatu proses dimana pemustaka perpustakaan untuk pertama kali diberi pemahaman dan pengertian sumber-sumber perpustakaan, termasuk pelayanan dan sumber-sumber informasi yang saling terkait, bagaimana menggunakan sumber-sumber tersebut, bagaimana pelayanannya dan dimana sumbernya).

Pengertian LUE menurut ODLIS (Online 
Dictionary for Library and Information Science) "activities involved in teaching users how t make the best possible use of library resources, services, and facilities, including formal and informal instruction delivered by a librarian or other staff member one-on-one or in a group. Also includes online tutorial, audiovisual materials, and printed guides and pathfinders (semua kegiatan yang terlibat dalam mengajar pengguna bagaimana memanfaatkan sebaik mungkin sumber daya perpustakaan, layanan, dan fasilitas, termasuk instruksi formal dan informal disampaikan seorang pustakawan atau anggota staf lain, individu atau kelompok. Juga termasuk tutorial online, bahanbahan audiovisual, dan panduan tercetak dan pathfinders.

Ada beberapa hal yang melatarbelakangi perlunya peran pendidikan pemustaka (LUE) di perpustakaaan perguruan tinggi, diantaranya adalah:

1. Sarana dan prasarana serta koleksi di perpustakaan merupakan suatu investasi yang sangat besar bagi perguruan tinggi, oleh karena itu perpustakaan harus digunakan dan dimanfaatkan secara maksimal oleh pemustaka

2. Pemustaka sebagian besar adalah mahasiswa yang ditekankan pada studi mandiri, sehingga diharapkan dengan pendidikan pemustaka akan mampu lebih memahami dan menggunakan perpustakaan dengan berbagai fasilitas dan layanannya secara lebih efektif dan efisien.

3. Dengan adanya kegiatan pendidikan pemustaka, maka perpustakaan harus mengatur dan membenahi dirinya agar dapat dipergunakan dengan mudah oleh pemustakanya.

Dengan adanya pendidikan pemustaka, maka membuka kesempatan bagi pustakawan untuk meningkatkan kualitas diri bukan hanya sebagai petugas yang hanya melayani pemustaka saja, tetapi ikut serta menyumbangkan pikiran dan keahliannya dalam meningkatkan kualitas layanan perpustakaan.

Hal-hal yang mendasari perlunya program LUE bagi mahasiswa di perguruan tinggi adalah:

1. Kemampuan mahasiswa dalam memanfaat- kan perpustakaan merupakan dasar yang amat penting dalam mencapai keberhasilan pendidikan.

2. Perpustakaan diharapkan mampu berfungsi dalam mendidik mahasiswa untuk menjadi pemustaka yang tertib dan bertanggung jawab.

3. Perpustakaan senantiasa berupaya agar segala kekayaan dalam bentuk koleksi, baik tercetak maupun terekan, segala fasilitas, dan layanan dapat digunakan secara maksimal oleh pemustaka

Tujuan utama diadakan pendidikan pemustaka adalah untuk memperkenalkan kepada pengguna bahwa perpustakaan adalah suatu sistem yang di dalamnya terdapat koleksi dan sumber informasi lain.

Menurut Rahayuningsih (dalam Prianto dan Haryani, 2015) tujuan dari diadakan pendidikan bagi pemustaka adalah: Supaya pengguna dapat menggunakan perpustakaan secara efektif dan efisien.

1. Pengguna dapat menggunakan sumber-sumber literatur dan dapat menemukan informasi yang relevan dengan masalah yang dihadapi.

2. Memberi pengertian kepada mahasiswa akan tersedianya informasi di perpustakaan dalam bentuk tercetak atau tidak.

3. Memperkenalkan kepada mahasiswa jenis-jenis koleksi dan ciri-cirinya

4. Memberikan latihan atau petunjuk dalam menggunakan perpustakaan dan sumber-sumber informasi agar pemakai mampu meneliti suatu masalah, menemukan materi yang relevan, mempelajari, dan memecahkan masalah

5. Mengembangkan minat baca penggunanya

6. Memperpendek jarak antara pustakawan dengan pemustakanya.

Jenis LUE Menurut Malley (dalam Prianto dan Haryani, 2015) membagi pendidikan pemustaka (LUE) ke dalam 2 hal yaitu: library Orientation dan Library Instruction.

\section{LO (Library Orientation)}

LO merupakan langkah awal dalam pelaksanaan 
pendidikan pemustaka di perguruan tinggi. Orientasi perpustakaan bertujuan untuk mengenalkan pemustaka tentang keberadaan perpustakaan dan layanan apa saja yang tersedia di perpustakaan juga memungkinkan pemustaka mempelajari secara umum bagaimana menggunakan perpustakaan, seperti: jam buka, jenis koleksi, letak koleksi tertentu, jenis layanan, cara meminjam koleksi perpustakaan, serta peraturan dan tata tertib.

Ratnaningsih (dalam prianto dan haryani, 2015) menjelaskan tujuan orientasi perpustakaan, yaitu: mengetahui fasilitas yang tersedia di perpustakaan, mengetahui kewajiban yang harus dipenuhi mengetahui tata letak gedung, ruang koleksi serta layanan yang tersedia, mengerti tata cara menggunakan katalog, komputer dan media teknologi lain.

\section{LI (Library Instruction)}

Definisi LI dalam ODLIS sama dengan definisi dalam bibliographic instruction, yaitu program-program instruksi yang didisain untuk mengajarkan pada pengguna perpustakaan bagaimana menemukan informasi secara cepat dan efektif. Pada saat ini, jumlah informasi yang dihasilkan dan yang dapat diakses terutama melalui internet tumbuh dengan pesat. Kemampuan untuk menggunakan berbagai macam bentuk informasi dengan efektif dan efisien sangatlah penting. Kemampuan ini disebut juga library literacy atau information literacy, merupakan komponen yang penting dalam pencarian informasi, mempromosikan pembelajaran seumur hidup dengan menyediakan bantuan yang tidak hanya untuk memperoleh informasi yang dibutuhkan, tetapi juga belajar untuk menemukan informasi apabila referensi bantuan tidak selalu tersedia.

Di perpustakaan akademik, LI biasanya berkaitan dengan kursus atau kursus-terintegrasi. Perpustakaan yang melaksanakan LI biasanya dilengkapi dengan laboratorium komputer untuk sesi praktek penggunaan katalog online, database bibliografi, dan sumber daya Internet. Instruksi biasanya diajarkan oleh pustakawan layanan instruksional dengan pelatihan khusus dan pengalaman dalam metode pedagogis. LI bertujuan agar para pemakai dapat memperoleh informasi yang diperlukan dengan tujuan tertentu dengan menggunakan semua sumber daya dan bahan yang tersedia di perpustakaan. Instruksi perpustakaan berkaitan dengan temu kembali informasi.

Tujuan LI menurut Ratnaningsih (dalam Prianto dan Haryani, 2015) adalah memberikan bimbingan bagi pemakai dengan tingkatan tertentu dengan tujuan sebagai berikut:

a. Mampu memanfaatkan perpustakaan secara efektif dan efisien.

b. Mempunyai rasa percaya diri yang tinggi dalam penemuan informasi.

c. Mampu menelusur informasi melalui sarana-sarana penelusuran informasi.

d. Memahami penelusuran bibliografi baik secara manual (katalog kartu) maupun dengan media teknologi (komputer, CD ROM dsb).

\section{Jenis-jenis LI :}

a. Point-of-Use Instruction. Beberapa penulis memberikan gambaran point-of-use instruction dengan informasi tercetak di perpustakaan yang memberikan penjelasan tentang alat dan koleksi referensi yang dipajang dimana alat dan koleksi tersebut diletakkan. Ketika pemustaka membutuhkan jawaban maka pustakawan memberikan gambaran yang sesuai dengan kebutuhan pemustaka.

b. Formal Instruction, merupakan salah satu aspek dari user education. Contoh: Tour dan Orientasi Perpustakaan; Presentasi di Kelas; Tutorial F.

\section{Metode LUE}

Metode Pendidikan Pemustaka dapat dilaksanakan secara baik, bila menggunakan metode yang tepat. Beberapa metode yang dapat diterapkan dalam pendidikan pemustaka di perguruan tinggi antara lain : ceramah, seminar, tutorial, demonstrasi, wisata perpustakaan, metode audio visual: film, video, tape, slide, latihan/praktek, program bimbingan kelompok, program bimbingan khusus, program bimbingan individu. 
Pelaksanaan Pendidikan Pemustaka di perguruan tinggi dilaksanakan dengan tata cara yang berbeda-beda pada setiap perguruan tinggi, misalnya:

1. Melaksanakan Pendidikan Pemustaka pada masa Orientasi Studi dan Pengenalan Kampus (ospek) Kegiatan pendidikan pemustaka yang disatukan dalam ospek tersebut diberikan pada materi khusus yang diselenggarakan selama kurang lebih 2 jam. Dengan materi mengenai pentingnya perpustakaan, jam buka perpustakaan.

2. Sarana temu kembali informasi, jasa perpustakaan, jenis koleksi yang dimiliki oleh suatu perpustakaan dan peraturan perpustakaan. Metode yang digunakan adalah:
a.Ceramah dengan prinsip pengenalan
b. Kunjungan perpustakaan
c. Demonstrasi atau peragaan

Pelaksana dalam pemberian pendidikan pemustaka pada tingkat ini adalah minimal pustakawan dengan kualifikasi setingkat sarjana muda ilmu perpustakaan.

3. Memasukkan dalam mata kuliah tertentu.

Pendidikan pemustaka dimasukkan melalui jalur kurikulum seperti dititipkan pada mata kuliah Kapita Selekta atau pada mata kuliah Metodologi Penelitian, dan bersifat wajib. Materi yang diberikan sama dengan materi orientasi, namun ada penekanan dalam materi pemustakaan yakni mengenai sarana temu kembali informasi (katalog, indeks, abstrak, dan bibliografi) dan juga penelusuran informasi otomasi. Metode yang digunakan adalah: ceramah dengan prinsip pengenalan, demonstrasi atau peragaan, praktek atau latihan.

4. Mewajibkan mahasiswa baru mengikuti program sebagai syarat mendapatkan kartu anggota perpustakaan. Metode yang digunakan adalah: ceramah dengan prinsip pengenalan, kunjungan perpustakaan, demonstrasi atau peragaan.

5. Melayani bagi yang berminat mengikuti program pendidikan pemustaka. Pendidikan pemustaka pada program ini bersifat bimbingan dan bisa dilakukan secara perorangan atau kelompok. Pelaksananya adalah pustakawan atau staf yang berkompeten. Metode yang digunakan adalah: Program Bimbingan Individu, Program Bimbingan Kelompok, Program Bimbingan Khusus

6. Pendidikan Pemustaka melalui Hompage seiring dengan makin mudahnya akses internet maka banyak perpustakaan yang memiliki website. Kegiatan pendidikan pemustaka akan lebih efisien dan efektif bila dilakukan melalui homepage yang bisa diakses oleh pemustaka. Fasilitas ini bisa diakses di manapun dan kapanpun oleh pemustaka. Informasi yang dimuat dalam website perpustakaan meliputi: a. Informasi kegiatan perpustakaan b. Petunjuk menggunakan perpustakaan c. OPAC dan data base CD-ROM (searching).

7. Pendidikan Pemustaka melalu berbagai media lainnya Pendidikan pemustaka dapat dilakukan melalui berbagai media baik yang tercetak seperti Bulletin Perpustakaan, Buku Panduan, dan Brosur, maupun yang terekam seperti film dan video.

\section{Pengguna Perpustakaan (Pemustaka)}

Pengguna atau pemakai perpustakaan merupakan faktor penting dalam sebuah perpustakaan. Pengertian pengguna atau pemakai menurut Undang-Undang Republik Indonesia Nomor 43 tahun 2007 tentang perpustakaan, yaitu: "Pemustaka adalah pengguna perpustakaan, yaitu perseorangan atau kelompok orang, masyarakat atau lembaga yang memanfaatkan fasilitas layanan perpustakaan". Pengertian lain menyebutkan bahwa pengguna adalah orang atau badan yang akan menggunakan perpustakaan.

Pengguna perpustakaaan dapat dikategorikan menjadi 2, yaitu: pengguna potensial dan Pengguna aktual. Pengguna potensial adalah masyarakat atau mereka yang belum sempat datang dan memanfaatkan jasa layanan perpustakaan, sedangkan yang dimaksud pengguna aktual adalah mereka yang sudah bisa memanfaatkan jasa layanan perpustakaan apapun bentuk layanannya. 


\section{Kriteria Pemustaka}

Pemustaka memiliki dua kriteria yaitu :

1. Kriteria objektif seperti kategori sosio-profesional, bidang spesialisasi, sifat kegiatan yang menyebabkan perlunya informasi, dan alasan menggunakan sistem informasi

2. Kriteria sosial dan psikologis seperti sikap dan nilai menyangkut informasi pada umumnya dan hubungannya dengan unit informal pada khususnya; sebab dan alasan yang berkaitan dengan prilaku mencari informasi dan komunikasi, perilaku sosial serta profesional Pemustaka.

Jenis Pemustaka dapat dinyatakan sebagai :

1. Pemustaka yang belum terlibat dalam kehidupan aktif seperti pelajar dan mahasiswa

2. Pemustaka yang mempunyai pekerjaan, informasi yang diinginkan merupakan informasi yang berkaitan dengan pekerjaan mereka.

\section{Karakter Pemustaka}

Perpustakaan perlu mengetahui beberapa karakteristik Pemustaka terutama dalam menunjang aktivitasnya. Penna (dalam Anwar 2015) mengungkapkan karakteristik tersebut adalah :

1. Individual or group yaitu apakah Pemustaka datang ke perpustakaan sebagai individu atau sebagai suatu kelompok.

2. Place of learning, yaitu tempat yang biasa digunakan oleh Pemustaka untuk membaca buku atau belajar.

3. Social situation, yaitu aspek sosial dari Pemustaka.

4. Leisure or necessity factor, yaitu apakah Pemustaka berkunjung ke perpustakaan untuk sekedar mengisi waktu luang atau karena dia membutuhkan buku atau informasi tertentu.

5. Subject of study, yaitu bidang apa yang sedang didalami Pemustaka. Apakah dia sedang menulis mengenai suatu subjek tertentu yang sangat khusus, atau sedikit lebih luas.

6. Level of study, yaitu tingkat pendidikan Pemustaka. Kebutuhan mahasiswa S1 tentu berbeda dengan kebutuhan mahasiswa tingkat S2 atau S3.

7. Motivation, yaitu sejauh mana keinginan dan antusiasme Pemustaka dalam memanfaatkan layanan perpustakaan.

\section{Penelitian Terdahulu}

Penelitian ini terinspirasi oleh beberapa penelitian terdahulu yang berkaitan baik dalam hal konsep maupun dinamika gagasan, antara lain sebagai berikut:

Rahayuningsih (2005) dalam artikel penelitiannya menjabarkan tentang pentingnya pendidikan bagi Pemustaka, bahwa Pendidikan pemustaka mengajarkan pada mahasiswa untuk mampu memanfaatkan seluruh fasilitas dan koleksi perpustakaan guna memenuhikebutuhan informasi yang diinginkannya. Pendidikan pemustaka memberikan dampak positif bagi keterampilan literasi informasi pada mahasiswa. Keterampilan litrasi informasi (information literacy skill) pada mahasiswa memungkinkan mahasiswa tidak hanya berhasil menempuh pendidikan dengan mudah namun juga memungkinkan seseorang lebih berhasil dalam setiap tahap kehidupannya.

MenurutUndang-Undang perpustakaan nomor 43 tahun 2007, "pustakawan adalah seseorang yang memiliki kompetensi yang diperoleh melalui pendidikan dan/pelatihan kepustakawanan serta mempunyai tugas dan tanggung jawab melaksanakan pengolahan dan pelayanan perpustakaan". Setiap pemustaka berhak untuk mendapatkan informasi yang relevan dan pelayanan optimal dari pustakawan.

Anwar (2015) dalam penelitiannya berjudul "Memahami Karakter Pemustaka" menjelaskan bahwa Pemustaka sendiri diartikan sebagai pengguna perpustakaan baik perseorangan, kelompok atau masyarakat yang memanfaatkan fasilitas layanan perpustakaan. Kajian tentang karater pemustaka merupakan bagian dari Psikologi Pemakai. Karakter adalah sifat manusia yang pada umumnya, setiap orang mempunyai karakter yang berbeda yang menjadi ciri khasnya. Jadi dapat diartikan bahwa karakter pemustaka adalah ciri-ciri dari pengguna yang menelusuri setiap informasi di sebuah perpustakaan. 


\section{TUJUAN PENELITIAN}

1. Memperkenalkan mahasiswa dan seluruh pengguna perpustakaan STIKI tentang kebijakan-kebijakan umum perpustakaan, mulai dari hal paling sederhana: prosedur menjadi anggota, tata cara, hingga tata tertib perpustakaan.

2. Memperkenalkan Teknik Pencarian judul Buku Katalog online (OPAC) kepada pengguna tentang pengorganisasian koleksi.

3. Menuju mahasiswa (pengguna) yang mandiri dan haus informasi.

4. Merumuskan strategi "pengajaran perpustakaan" (library instruction) di perpustakaan STIKI

\section{MANFAAT PENELITIAN}

1. Memotivasi pengguna perpustakaan untuk lebih dekat dengan dunia perpustakaan.

2. Mengurangi kebingungan pengguna perpustakaan dalam mencari bahan pustaka yang dibutuhkan.

3. Mengoptimalkan peran dan fungsi perpustakaan sepanjang masa.

4. Memberikan Pelatihan dan Program tutoring (LUE) sebagai agenda rutin perpustakaan STIKI tentang kemudahan menggunakan layanan perpustakaan secara berkesinambungan.

\section{METODE PENELITIAN}

Penelitian ini menggabungkan kedua metode, baik secara kualitatif maupun kuantitatif. Durasi pelaksanaan penelitian disesuaikan dengan kelengkapan perolehan data dan ditelusuri dari hasil kelengkapan wawancara, pemantauan kunjungan, perhitungan data visitor, temuantemuan penunjang di lapangan.

Pengumpulan data dilakukan dengan langkahlangkah:

1. Pengamatan dan dokumentasi.

a. Mengamati tujuan mahasiswa di setiap kunjungan ke ruang perpustakaan, memantau motivasi kunjungan mahasiswa.

b. Me-list kualifikasi dan kuantitas bahan pustaka yang dibutuhkan Pengunjung.

c. Merekam dan mengevaluasi proses kegiatan dari pengunjung d. Mendata jumlah visitor per akhir bulan

e. Menarik kesimpulan sementara terhadap hasil evaluasi proses kegiatan pengunjung guna menemukan sejauh mana pengunjung membutuhkan edukasi tentang peran perpustakaan.

2. Penyebaran kuesioner

Penyebaran kuesioner dilakukan secara langsung kepada responden (mahasiswa, dosen, karyawan, alumni, publik) secara acak, baik yang berkunjung ke perpustakaan STIKI maupun yang berada di seputar kampus STIKI. Adapun jenis kuesioner yang disebarkan berupa daftar pertanyaan multiple choice dan beberapa penjelasan essay sesuai pengalaman kegiatan pengguna selama ini, seperti pada figur berikut.
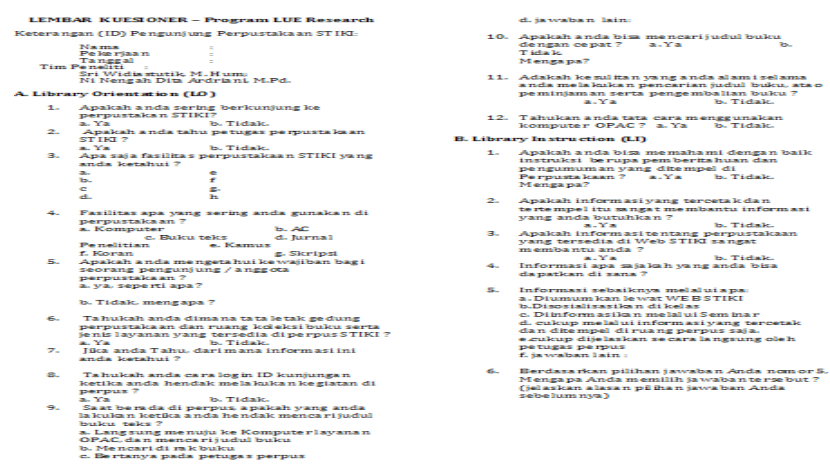

Figure 4.1 angket kuesioner

Berdasarkan angklet tersebut diperoleh data tentang kebutuhan responden dalam 2 hal penilaian: HM dan PR terhadap pengaruh positif dan negatif pelaksanaan LUE bagi mereka sebagai data utama dalam penelitian ini.

\section{Wawancara}

Wawancara dilakukan guna melengkapi informasi dan hasil rekaman pemantauan sebagai pembanding akurasi jawaban pentingnya program edukasi (LUE) bagi pengguna (pemustaka). Teknik wawancara dilakukan terhadap pengguna secara random per minggu, baik kepada mahasiswa, alumni, staf maupun dosen. Proses ini dilakukan sebagai data tambahan (sekunder) yang melengkapi data utama dalam penelitian ini.

Proses pengolahan data dalam penelitian ini, 
antara lain: mengkompilasi dan mengklasifikasi hasil penelitian dengan menggunakan pendekatan kuatitatif dan kualitatif deskriptif yang dikombinasikan dengan teknik-teknik pengumpulan data tersebut di atas, dengan langkah-langkah berikut.

1. Penelusuran literatur.

2. Secara Kualitatif mendeskripsikan masalah dalam kerangka pembahasan yang telah ditetapkan.

3. Secara Kuantitatif memprosentase tingkat keperluan pengguna terhadap peran edukasi

4. Menentukan instrument penelitian untuk mengukur jenis kebutuhan pengguna

Analisa data terhadap hasil temuan di lapangan. Adapun langkah-langkah menganalisa data dalam penelitian ini, meliputi:

1. Data utama diklasifikasi dan dicek kesesuai/ tidaksesuaian kebutuhan data berdasarkan kerangka teori

2. Instrumen data hasil wawancara (data tambahan) dikembangkan guna mengukur kondisi kebutuhan program edukasi.

3. Membandingkan jenis LUE (data hasil LI dan LO) berdasarkan teori Malley untuk mengetahui sasaran utama yang perlu di-edukasi.

Langkah terakhir menyimpulkan kebijakan terhadap perlunya dilakukan program edukasi bagi pengguna perpustakaan, baik mahasiswa, alumni, dosen, staf STIKI maupun masyarakat umum diharapkan telah sesuai dengan kebutuhan layanan perpustakaan dan kebutuhan pemustaka.

Berdasarkan fakta di lapangan selama ini, jenis layanan yang disediakan sangat dibutuhkan oleh pengguna dan beberapa bentuk layanan yang paling diminati untuk semua pengguna perpustakaan, seperti kegiatan baca Koran (bagi dosen), bentuk layanan ruang baca buku banyak diminati oleh mahasiswa. Bentuk layanan lain yang diminati adalah layanan internet gratis untuk menunjang kuliah online (bagi semua: dosen, mahasiswa, karyawan. alumni).

Jumlah koleksi perpustakaan pada saat ini 5510 eksemplar yang terdiri dari koleksi buku teks \& tutorial berbahasa Indonesia dan Inggris, 39 koleksi referensi, koleksi majalah ilmiah 39 judul jurnal nasional (62 eks), 23 judul jurnal internasional (23 eks), 998 koleksi skripsi, dan 1039 koleksi karya $\mathrm{KP}$, karya ilmiah/laporan penelitian, seperti dapat dilihat pada tabel 1 berikut:

Tabel 1. Jenis Koleksi Pustaka STIKKI

\begin{tabular}{|l|r|c|}
\hline \multirow{2}{*}{\multicolumn{1}{c|}{ Jenis Koleksi }} & \multicolumn{2}{c|}{ Jumlah } \\
\cline { 2 - 3 } & Judul & Eksemplar \\
\hline Koleksi Buku, & 4266 & 5510 \\
\hline Koleksi skripsi & 998 & 998 \\
\hline Koleksi Jurnal & 62 & 85 \\
\hline Koleksi majalah tercetak/buletin & 65 & 112 \\
\hline Koleksi bacaan fiksi (novel/cerpen) & 106 & 212 \\
\hline Modul perkuliahan (proses input) & 20 & 20 \\
\hline Karya ilmiah/Penelitian & 65 & 65 \\
\hline
\end{tabular}

(Sumber : perpus stiki, 2017)

\section{Sistem Layanan Perpustakaan STIKI}

Dalam layanannya, perpustakaan STIKI menggunakan sistem layanan terbuka (open access), dimana pemustaka dapat langsung memilih, mengambil dan membaca buku koleksi yang dibutuhkan, tersedia di rak secara langsung. Koleksi Perpustakaan merupakan koleksi yang bisa dibaca di tempat.

Pemustaka dapat langsung melihat dan menelusur di OPAC dari komputer di jaringan local house perpustakaan. Pemustaka bisa memilih buku yang tersedia dan bisa langsung konfirmasi kepada petugas perpustakaan untuk meminjam. Pemustaka dapat meminjam buku selama 7 hari maksimal 3 buku dan dapat diperpanjang 3x (=3 minggu).

Perpustakaan STIKI telah menerapkan sistem informasi berbasis komputer dengan automasi perpustakaan Senayam Library Information Management System (SLIMS) yang merupakan aplikasi sistem yang terintegrasi. penelusuran koleksi perpustakaan menggunakan OPAC. Sistem informasi perpustakaan sudah menggunakan program pengadaan Intranet server manual.

Dalam melaksanakan tugasnya sehari-hari, Perpustakaan STIKI mempunyai personalia yang terdiri dari 1 orang kepala perpustakaan dan 2 orang staf perpustakaan yang berlatar belakang pendidikan D3 ilmu perpustakaan. Penanganan 
layanan peminjaman dan pengembalian dilakukan oleh kepala dan staf perpustakaan. Kepala perpustakaan memiliki kualifikasi pendidikan S2 non-perpustakaan tetapi sudah dibekali kemampuan dan pelatihan. Bila terdapat kendala dalam melaksanakan tugasnya, maka kerjasama di antara seluruh personil sangat diutamakan. Petugas yang menemui masalah akan langsung berkoordinasi kepada kepala perpustakaan dan personil lainnya guna pelayanan yang baik dan benar. Adapun jam buka layanan perpustakaan STIKI dilaksanakan setiap hari kerja yaitu mulai dari hari Senin hingga hari Sabtu, dengan waktu buka yaitu: jam 08.30 22.00 WIB.

\section{Hasil Rekapan Kunjungan Pengguna Perpustakaan STIKI}

Data hasil rekapan Kunjungan Pengguna Perpustakaan STIKI dapat dilihat dari tabel berikut. Berdasarkan hasil rekapan perbandingan dari 2 tahun terakhir menunjukkan bahwa pada tahun akademik 2014/2015 jumlah pengunjung perpustakaan masih dihitug secara manual dengan total jumlah 2806 kunjungan. Sedangkan kunjungan di tahun berikutnya tahun akademik 2015/2016 mulai dihitung berdasarkan rekap komputer visitor menunjukkan kenaikan kunjungan mendekati 3x lipat lebih tinggi (300\%).

Tabel 2. Perbandingan Kunjungan Perpustakaan STIKI

\begin{tabular}{|c|c|c|c|c|}
\hline Belax & 201422015 & $2015 / 2016$ & prosentas ol wasils & $2016 / 2017$ \\
\hline Bsten 1 (3⿻日) & 140 & 456 & $300 \%$ & 260 \\
\hline Bstan 2 (Oet) & 135 & 697 & $450 \%$ & 582 \\
\hline Bolan 3 (Nov) & 124 & 521 & $415 \%$ & 1137 \\
\hline Bollen 4 (Dos) & 319 & 516 & $175 \%$ & 1212 \\
\hline Bsolen 5 (12n) & 595 & 653 & $120 \%$ & \\
\hline Bकsing $6(\bar{c} 6)$ & 292 & 304 & $109 \%$ & \\
\hline Bolan 7 (ax) & 349 & 590 & $190 \%$ & \\
\hline Belsn 3 (Agr) & 373 & 1252 & $365 \%$ & \\
\hline Bolng 9 (asy) & 226 & 1048 & $450 \%$ & \\
\hline Bolen 10 (fva) & 128 & 361 & $672 \%$ & \\
\hline Bolva 11 (fwi) & 72 & 326 & $400 \%$ & \\
\hline Belan 12 (wav) & 53 & 138 & $225 \%$ & \\
\hline Jumlab & 2805 & 7352 & $300 \%$ & 3191 \\
\hline
\end{tabular}

Jika melihat hasil rekapan sementara selama 6 bulan terakhir (semester ganjil) di tahun akademik 2016/2017, dengan nilai total sementara 3191 kunjungan, dapat diasumsikan sudah mencapai
50\% dari total kunjungan 1 tahun sebelumnya (di tahun akademik 2015/2016). Adapun data kunjungan tersebut seperti ditampilkan dalam grafik berikut ini.

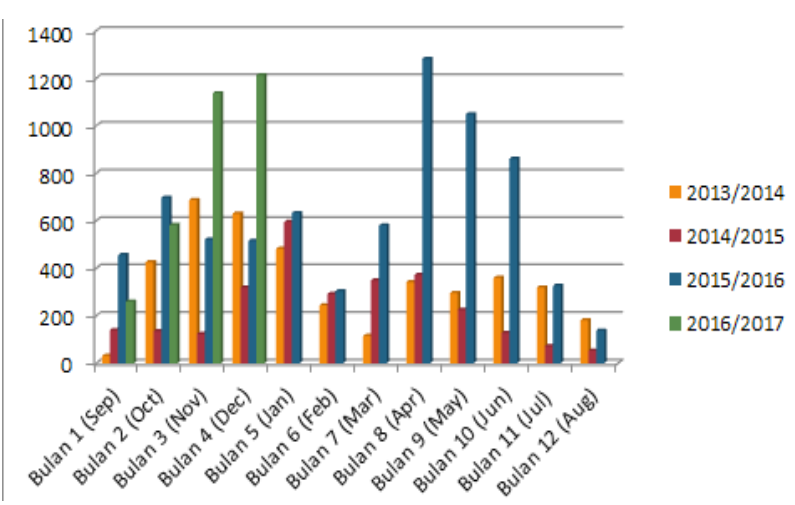

Diagram 1 Sumber: Perpustakaan STIKI 2016

Drastisnya kenaikan jumlah kunjungan tersebut jika dikorelasikan dengan harapan besar pengguna terhadap pelaksanaan LUE, dapat disimpulkan sementara bahwa sejak diterapkan program edukasi (LUE) terhadap pengguna berpengaruh positif terhadap pemahaman pengguna yang mendapatkan tambahan pengetahuan tentang tata cara kegiatan di perpustakaan, lebih lancar melakukan aktifitas di ruang perpus sesuai dengan informasi yang dipahami oleh pemustaka, serta menjadi lebih percaya diri datang ke perpustakaan STIKI sesuai dengan butir pernyataan responden tentang dampak yang dirasakan dengan diterapkannya LUE.

\section{Deskripsi Pengguna Perpustakaan STIKI}

Tabel 3. Deskripsi Pengguna

\begin{tabular}{|l|c|c|}
\multicolumn{1}{c|}{$\begin{array}{c}\text { Pengguna } \\
\text { Perpustakaan }\end{array}$} & Sebelum LUE & Sumlah \\
\hline Dosen & 35 & 98 \\
\hline Mahasiswa & $\mathbf{1 2 0 0}$ & 3434 \\
\hline Karyawan & 11 & 25 \\
\hline Jumlah & $\mathbf{1 2 4 6}$ & $\mathbf{3 4 6 7}$ \\
\hline
\end{tabular}

Dari hasil kuesioner diperoleh data responden yang berkunjung ke perpustakaan berdasarkan Program studi/jurusan dan angkatan menunjukkan pengguna dari Program Studi TI $84 \%$, pengguna dari Program studi SK 10\%, sedangkan pengguna dari dosen 10 orang atau 5\%, karyawan 2 orang $=1 \%$ dari seluruh jumlah responden 100 orang. Dengan demikian responden yang paling banyak 
berkunjung ke perpustakaan adalah mahasiswa dari program studi TI.

\section{Deskripsi Frekuensi Kunjungan Responden ke Perpustakaan}

Berdasarkan hasil angket kusioner tentang tingkat banyaknya waktu berkunjung dalam seminggu perpustakan buka menurut responden di atas menunjukkan seberapa sering responden berkunjung ke perpustakaan dalam seminggu (dapat dilihat pada diagram 2 berikut).
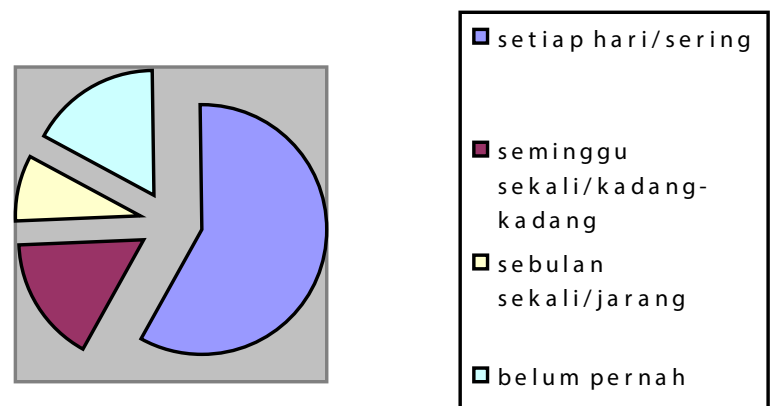

Diagram 2 Deskripsi Berdasarkan Jenis Kunjungan Responden

Berdasarkan pendapat respoden bahwa $67 \%$ responden menyatakan berkunjung setiap hari/sering sekali ke perpustakaan, 19\% responden menyatakan berkunjung seminggu sekali/kadang kadang, $12 \%$ responden menyatakan berkunjung sebulan sekali/jarang, dan $2 \%$ belum pernah berkunjung. Dari hasil di atas terlihat jelas mayoritas responden berkunjung ke perpustakaan setiap hari. Hal ini menunjukkan keberadaan perpustakaan dibutuhkan dan menjadi tujuan pengguna ketika berada di lingkungan kampus.

Berikut jawaban mengenai kunjungan responden tentang peran LUE
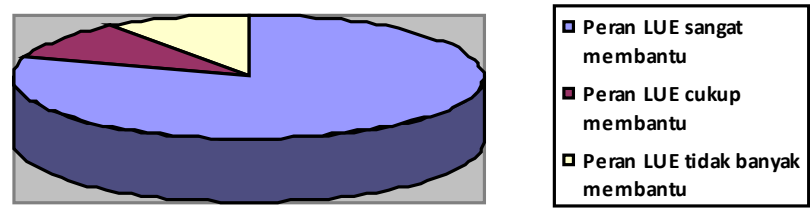

Diagram 3. Deskripsi Berdasarkan manfaat pelaksanaan LUE

Diagram 3 di atas menunjukkan seberapa besar manfaat LUE berdampak bagi pengguna perpustakaan STIKI. Sebanyak 80\% responden menjawab bahwa LUE sangat membantu memahami tata cara peminjaman, tata cara login anggota di komputer visitor, tatacara mengecek judul buku di OPAC. 10\% responden menjawab dengan adanya LUE cukup membantu mencari judul buku di OPAC, namun tetap memilih lebih terbiasa dibantu langsung oleh petugas perpustakaan, $10 \%$ responden tidak berpengaruh, pengguna tetap bertanya pada petugas secara langsung pada saat bingung mencari judul buku apalagi jika jaringan internet tidak stabil. Dari data tersebut mayoritas responden dalam hal ini pengguna perpustakaan datang ke perpustakaan merupakan kebutuhan dan demi kelancaran proses belajar di perpustakaan. Terkait hanya 20\% responden yang menyatakan bahwa peran LUE kurang berpengaruh dikarenakan ada gangguan teknis listrik ataupun gangguan jaringan internet yang menghambat pengguna login maupun cek judul buku secara online di computer, sehingga terkadang ini memakan waktu cukup lama.

\section{Analisis Peran LUE bagi Pemustaka}

Secara garis besar kualitas layanan perpustakaan melalui peran LUE bagi pemustaka STIKI dalam penelitian ini dianalisa berdasarkan beberapa sudut pandang pemahaman pengguna perpustakaan STIKI, sebagai berikut.

\section{Tabel 4. Deskripsi Pengguna terhadap Peran LUE}

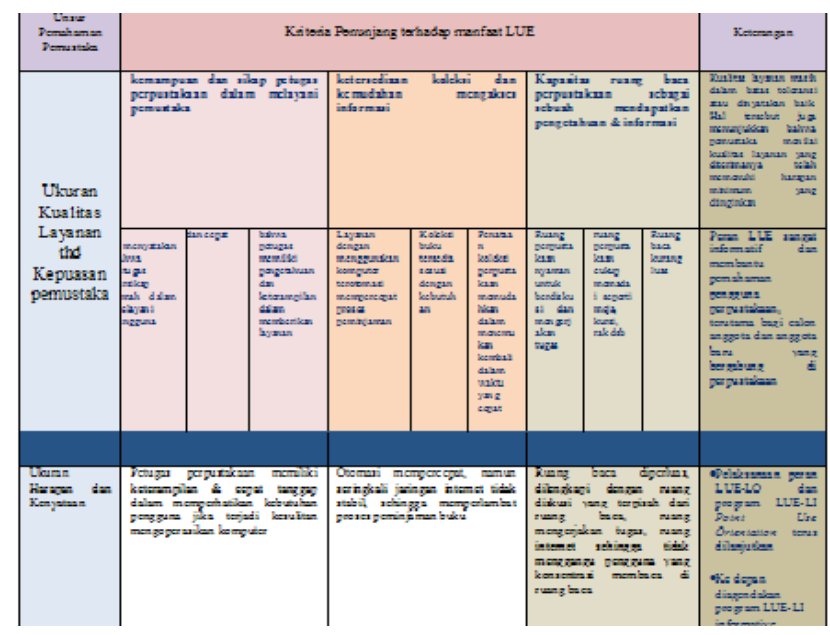

Dengan demikian, identifikasi, ukuran dan 
gambaran kualitas layanan perpustakaan dan tingkat kepuasan pemustaka yang merupakan hasil dari penelitian ini menjadi jelas. Sehingga memudahkan bagi manajemen perpustakaan untuk mengambil langkah-langkah perbaikan di masa yang akan datang. Skor nilai positif - nilai negatif hendaknya mendapat perhatian dari manajemen perpustakaan STIKI. Dalam kegiatan pelayanan memerlukan suatu sikap positif di hadapan pemustaka. Senyum, tutur kata, gerak gerik dan kecekatan dalam melayani akan memberikan nilai tambah yang besar bagi kepuasan pemustaka. Dalam melakukan pelayanan yang baik maka sikap dan perhatian adalah dasar bagi perpustakaan untuk memberikan pelayanan secara nyata untuk melakukan tindakan terbaik yang terwujud menjadi satu-kesatuan dalam melayani pemustaka.

Responden menyatakan puas dengan adanya layanan internet di perpustakaan membantu pemustaka dalam mengakses informasi, responden juga menyatakan cukup puas terhadap kejelasan petunjuk dan panduan penggunaan fasilitas layanan di perpustakaan, responden menyatakan puas dengan keberadaan sarana computer OPAC di perpustakaan cukup memadai, namun yang harus mendapat perhatian menurut responden adalah dalam penataan koleksi perpustakaan (buku, bahan referensi, skripsi, majalah ilmiah, dsb.) memudahkan pemustaka dalam menemukan kembali, sumber informasi lain seperti (skripsi, bahan referensi, majalah ilmiah, dsb) dibutuhkan pemustaka untuk menyelesaikan/ mengerjakan tugas-tugas. Otomasi perpustakaan dengan komputer membuat layanan sirkulasi menjadi lebih cepat dan fasilitas katalog online / OPAC membuat penelusuran informasi di perpustakaan menjadi mudah.

Dalam penataan koleksi dalam sistem layanan terbuka memang terkendala dengan mewujudkan koleksi dalam kondisi yang rapi sepanjang waktu dalam jajaran koleksi di perpustakaan, pemustaka dapat langsung masuk ke dalam rak koleksi untuk mencari buku yang dibutuhkannya, sehingga petugas harus selalu memperhatikan penataan koleksi. Otomasi perpustakaan membutuhkan perangkat komputer yang bagus agar pelayanan menjadi cepat, ketersediaan komputer menjadi prioritas un- tuk mendukung kegiatan perpustakaan dari mulai pengadaan, pengolahan, sirkulasi sampai dengan pemeliharaan bahan pustaka.

Demikian juga untuk mendukung fasilitas OPAC dibutuhkan perangkat unit komputer yang memadai sehingga pemustaka dapat melakukan penelusuran koleksi perpustakaan dengan cepat. Responden menyatakan puas dengan fasilitas gedung dan peralatan fisik (rak, meja baca, kursi, dsb.) di perpustakaan cukup memadai dan responden menyatakan puas dengan suasana perpustakaan mengundang pemustaka untuk selalu berkunjung, namun yang harus mendapat perhatian adalah ruang perpustakaan memberi inspirasi penulis untuk membaca dan belajar serta sebagai penyedia tempat belajar yang nyaman.

\section{KESIMPULAN \& SARAN}

Pendidikan pemustaka (LUE) di perguruan tinggi tidak selamanya dapat terlaksana dengan baik. Faktor-faktor yang menjadi hambatan dalam Pendidikan Pemustaka antara lain : kurangnya fasilitas perpustakaa, belum terjalinnya kerjasama antara pustakawan dan pemustaka, kurangnya tenaga pustakawan professional. LUE merupakan kegiatan yang sangat penting dilakukan di Perpustakaan Perguruan Tinggi. LUE mengajarkan pada mahasiswa untuk mampu memanfaatkan seluruh fasilitas dan koleksi perpustakaan guna memenuhi kebutuhan informasi yang diinginkan. Pendidikan pemustaka memberikan dampak positif bagi keterampilan literasi informasi pada mahasiswa. Keterampilan literasi informasi (information literacy skill) pada mahasiswa memungkinkan mahasiswa tidak hanya berhasil menempuh pendidikan dengan mudah namun juga memungkinkan seseorang lebih berhasil dalam setiap tahap kehidupannya.

Dari hasil penelitian ini maka dapat ditarik kesimpulan kualitas layanan Perpustakaan STIKI dari sudut pandang pemustaka. Berikut ini adalah rincian dari kesimpulan penelitian:

Berdasarkan jenis LI yang bisa diterapkan di perpustakaan STIKI sesuai dengan hasil pendapat responden, adalah: jenis Point-of-Use Instruction. Hasil penerapan model LI point-of- 
use instruction di perpustakaan STIKI berdampak positif, antara lain berupa pemberian informasi tercetak yang ditempel di perpustakaan, berisi penjelasan tentang petunjuk dan kode koleksi referensi yang dipajang di dinding ruang baca dan di rak-rak buku. Khususnya informasi yang langsung disampaikan oleh petugas perpustakaan tentang cara login sebelum melakukan transaksi/ kegiatan di perpus, lokasi komputer OPAC, meja layanan sirkulasi, meja staf, dll. Ketika pemustaka membutuhkan jawaban maka pustakawan memberikan gambaran yang sesuai dengan kebutuhan pemustaka. Sedangkan jenis LI - Formal Instruction belum bisa diterapkan sementara ini, dan akan ditinjau ulang sesuai tuntutan kebutuhan pemustaka ke depan. Sejauh ini, jenis FI inipun merupakan masukan program LUE yang bisa dijadikan sebagai salah satu aspek dari user education program. Contoh: Tour dan Orientasi Perpustakaan; Presentasi di Kelas; Tutorial F.

Tabel 5. Perhitungan Harapan Minimum Vs Pendapat Responden

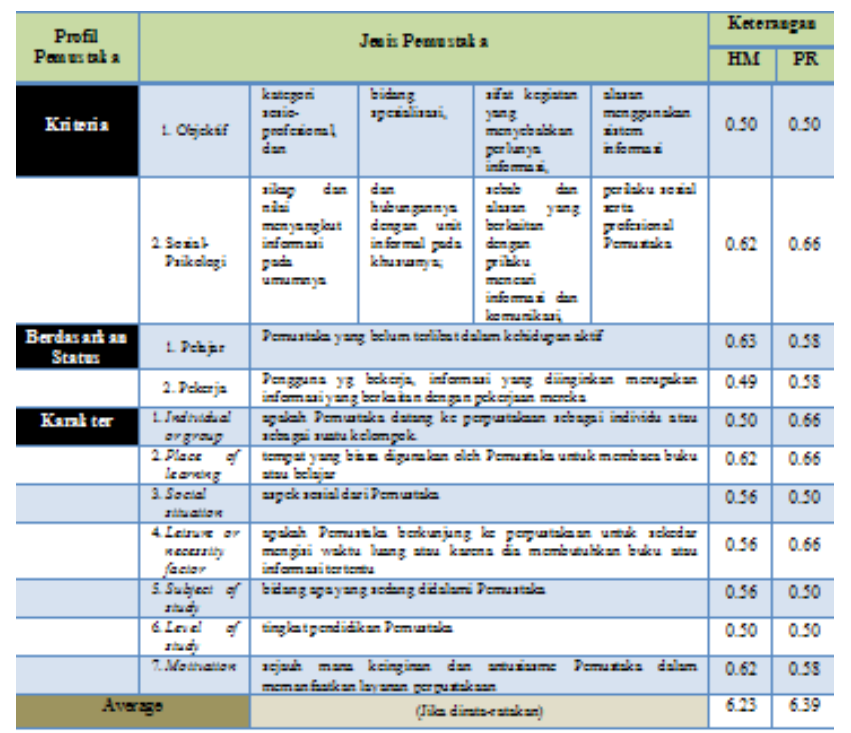

Jika dilihat dari jawaban responden terhadap peran LUE dan dampak yang dirasakan bagi reponden, menunjukkan bahwa pengguna perpustakaaan STIKI cenderung dikategorikan sebagai pengguna aktual, yakni $\geq 90 \%$ mereka sudah bisa memanfaatkan jasa layanan perpustakaan apapun bentuk layanannya. Sedangkan $\leq 10 \%$ dikategori- kan sebagai pengguna potensial, terutama mereka yang belum sempat datang dan memanfaatkan jasa layanan perpustakaan. Adapun kriteria pemustaka tersebut sesuai dengan alasan kebutuhan terhadap perpustakaan dari perhitungan HM \& PR seperti terlihat pada tabel 5 .

Evaluasi atau uji kontrol terhadap informasi yang ada di perpustakaan merupakan nyawa perpustakaan dan harta yang tiada ternilai bagi ilmu pengetahuan yang dapat dimanfaatkan oleh pemustaka sepanjang masa dan pekerjaan sekaligus ladang amal bagi pustakawan atau petugas perpustakaan. Hal ini perpustakaan dituntut untuk menyediakan koleksi yang memadai dan kemudahan akses untuk temu balik informasi, dan mengakses informasi pada saat dibutuhkan pemustaka termasuk penyediaan peralatannya serta kenyamanan menggunakan fasilitas perpustakaan tersebut. Berdasarkan pernyataan responden selain automasi perpustakaan, layanan yang banyak diminati dan mempengaruhi kepuasan pemustaka adalah layanan internet di perpustakaan. Kemudahan akses informasi bagi pemustaka saat ini menjadi penting karena kebutuhan pemustaka terhadap informasi semakin luas sehingga di perpustakaan selain menyediakan koleksi secara tercetak dan digital, juga dituntut oleh pemustaka agar meluaskan layanan untuk memberikan akses informasi tanpa harus terikat pada lokasi dan waktu tertentu. Secara keseluruhan dapat disimpulkan:

1. Pemustaka perpustakaan STIKI sangat membutuhkan program LUE diterapkan bagi kelancaran dan kemampuan pemustaka selama melakukan kegiatan di perpus

2. Banyak informasi istilah teknis perpustakaan yang perlu disosialisasikan kepada pemustaka:

a) Kualitas layanan Perpustakaan stiki dari sudut pandang mahasiswa sebelum program edukasi pengguna (LUE) disosialisasikan di perpustakaan STIKI. Dengan rincian butir pernyataan responden: Petugas aktif menanyakan kebutuhan pengguna; Petugas dapat memberikan informasi tambahan kepada pengguna terhadap koleksi yang dibutuhkan; Petugas dengan cepat memberikan jawaban atas permintaan 
informasi yang dicari; Buku-buku koleksi perpustakaan sesuai dengan kebutuhan pengguna.

b) Kualitas layanan Perpustakaan STIKI dari sudut pandang dosen, yakni: Jumlah buku yang bisa dipinjam supaya ditambah kuantitasnya supaya dapat memenuhi sesuai dengan kebutuhan; Jam layanan perpustakaan telah sesuai dengan kebutuhan; Penataan koleksi perpustakaan memudahkan dalam menemukan kembali dalam waktu yang cepat; Koleksi jurnal tercetak sesuai dengan kebutuhan; Buku-buku koleksi perpustakaan sesuai dengan kebutuhan pengguna; Otomasi perpustakaan dengan komputer membuat layanan menjadi lebih mudah; Layanan dengan menggunakan komputer terotomasi mempercepat proses peminjaman; Fasilitas catalog online membantu dalam menelusuri koleksi secara mandiri yang dicari; Fasilitas ruang perpustakaan cukup memadai seperti meja, kursi, rak dsb. Hanya saja 2 hal yang kurang sesuai bagi dosen adalah lama peminjaman buku kurang sesuai dengan kebutuhan pengguna; dan katalog online hanya bisa diakses local house saja, belum bisa diakses dari rumah sehingga harus hadir di perpustakaan dengan jarak yang cukup jauh.

Berdasarkan hasil perhitungan nilai ratarata harapan minimum (HM) sebesar 6,23 dan nilai rata-rata pendapat Responden (PR) terhadap Peran LUE sebesar 6,39. Dari nilai tersebut maka dapat diketahui bahwa nilai rata-rata PR lebih tinggi dari HM, sehingga diperoleh nilai kesenjangan sebesar o,16. Secara umum kualitas layanan perpustakaan dari sudut pemustaka di nilai baik dinilai oleh penggunannya.

Berangkat dari kesimpulan tersebut maka penulis memberikan saran dan masukan kepada manajemen perpustakaan STIKI, sebagai berikut:

1. Perlu dilanjutkan secara rutin agenda program
LUE - LO setiap tahun bagi pengguna STIKI

2. Khususnya Program LUE-LI diagendakan sebagai program edukasi bagi pengguna perpustakaan STIKI selanjutnya sebagai wujud keselarasan program LUE-LO yang sudah berjalan.

3. Perlu ditetapkan strategi pengembangan sumber daya manusia berkaitan dengan padatnya rutinitas petugas perpustakaan, sehingga kesulitan petugas membagi tugas antara layanan sirkulasi, penginputan, pengklasifikasian buku, pelabelan katalog buku, layanan terhadap pengunjung (welcome service) dapat terlayani secara optimal sebagaimana keinginan pemustaka untuk dilakukan penambahan petugas perpustakaan khususnya membantu pemustaka mencari buku.

4. Layanan internet di perpustakaan STIKI, sangat diminati oleh pemustaka, untuk peningkatan fasilitas layanan internet maka diperlukan penambahan jumlah unit komputer yang dapat digunakan pemustaka dalam mengakses informasi, dan melengkapi ruangan internet gratis, menstabilkan jaringan wifi secara maksimal.

5. Dengan tersedianya fasilitas katalog online (OPAC) pemustaka dapat dengan mudah melakukan penelusuran informasi koleksi di perpustakaan, untuk itu diperlukan penambahan jumlah unit komputer untuk katalog online, saat ini yang disediakan baru satu unit.

6. Pemustaka mengharapkan penambahan buku baik secara kualitas maupun kuantitas. Perpustakaan diharapkan meningkatkan hal tersebut setiap tahun dalam rangka menunjang kegiatan belajar-mengajar.

7. Untuk meningkatkan kenyamanan pemustaka di perpustakaan perlu didirikan ruang sirkulasi dan repository khusus, serta perluasan ruang baca, sehingga diharapkan pemustaka agar semakin betah di perpustakaan dan dapat memunculkan inspirasi untuk selalu belajar dan membaca di perpustakaan

Demikian hasil penelitian ini, semoga bermanfaat bagi semua pihak yang berkepentingan.

\section{DAFTAR PUSTAKA}

Anonim. 2013. ODLIS-Online Dictionary for Library 
and Information Science. IBLims: diakses dari Perpustakaan Politeknik KP Sidoarjo

Anwar, Ahmad. 2015. Memahami Karakter Pemustaka.

IBLims:http://ahmad-cahperpus.blogspot.com/2012/04/ v-behaviorurldefaultvmlo_3o.html

Arikunto, Suharsimi. 2009. Prosedur Penelitian ; Suatu pendekatan praktek edisi revisiVI. Jakarta: Rineka Cipta

Basuki, Sulistyo. 1991. Pengantar Ilmu Perpustakaan. Jakarta: Gramedia

Barata, Atep Adya. 2010. Dasar-Dasar Pelayanan Prima. Jakarta: Elex MediaKomputindo

Bungin, Burhan, 2005. Metodologi Penelitian Kuantitatif Komunikasi, Ekonomi,dan Kebijakan Publik serta Ilmu-Ilmu Sosial Lainnya, Edisi Pertama

Darmono. 2001. Manajemen dan Tata Kerja Perpustakaan Sekolah. Jakarta: PT Gramedia

Davis, MaShana dan Kyrillidou.LibQUAL+ .Procedures Manual. 2009. Washington D.C: Association of Reaseach Libraries

Departemen Pendidikan Nasional RI. 2004. Perpustakaan Perguruan Tinggi ; BukuPedoman. Edisi ketiga. Jakarta: Direktorat Jendral Pendidikan Tinggi

Departement Pendidikan Nasional. 2005. Kamus Besar Bahasa Indonesia. Jakarta: Balai Pustaka

Gasperz, Vincent. 1997. Manajemen Kualitas dalam Industri Jasa. Jakarta: Yayasan Indonesia Emas

Gronroos, Christian. 1990. Service Management and Marketing; Managing the moments of Truth in service competition. Singapore: Maxwell Macmillan

Handoko T. Hani. 200o. Manajemen Personalia dan Sumberdaya Manusia, Edisi II, Cetakan Keempat Belas. Yogyakarta: Penerbit BPFE

Harmawan. 2014. Manajemen Pemasaran dan Implementasikan di Perpustakaan http:// Byupustakawan. Wordpress.com

Haryani. 2012. Pendidikan Literacy Informasi di Perpustakaan Perguruan Tinggi. IBLims

Hernon, Peter dan Nitecki, Danuta A. 2009. Service Quality: A Concept Not Fully Explored. Library Trends Vol. 49(4) Spring, 687-707

Hinton, Peter. 1993. Quality Public Service Finance and Management. Great Britain: Tudor Business

IBLims. 2015. Pendidikan Pemustaka (User Education) di Perpustakaan Perguruan Tinggi. Posted by Mardiah http://bpsdmkp.kkp.go.id/apps/perpustakaan
Indarti, Widya. 2016. Peran Perpustakaan Perguruan Tinggi Dalam Proses Pembelajaran. IBLims: STP Jakarta

Indonesia. Undang-Undang No. 20 Tahun 2003 Tentang Sistem Pendidikan Nasional

Indonesia. Undang-Undang No. 43 Tahun 2007 Tentang Perpustakaan

Kotler, Philip dan Keller, Kevin Lane. 2012. Manajemen Pemasaran ; Edisi Kedua Belas Jilid 1. jakarta: Indeks

Lupiyoadi, Rambat dan Hamdani, A. 2008. Manajemen Pemasaran Jasa ;Edisi 2.Jakarta: Salemba Empat

Mathews, Joseph R. 2007. The Evaluation And Measurement of Library Services

McGraw-Hill, 1999. Marketing Information Products and Services ; A primer for librarian and information professionals

Moleong, Lexy. 2005. Metode Penelitian Kualitatif Bandung: PT. Remaja Rosdakarya

Munir. 2009. Kurikulum Berbasis TIK. Bandung: Alfabeta Narendra, Pramukti. 2010. Survey dan penelitian perpustakaan untuk mengetahui kebutuhan pemustaka

ODLIS, Online Dictionary for Library and Information Science. http://www.abc-_clio.com/ODLIS/odlis_A.aspx / Diakses 4 September 2013

Perpustakaan Nasional R.I. 2002. Pedoman Teknis Pengembangan Koleksi Layanan Perpustakaan Nasional R.I./Nelwaty, Lily Suarni. - Jakarta: Proyek Pembinaan dan Pengembangan Perpustakaan Nasional R.I.

Prianto, Sugeng, Haryani. 2011. User Education and Library Instruction di Perpustakaan Perguruan Tinggi. IBLims

Rahayuning, F. 2005. Mengkaji Pentingnya Pendidikan Pemustaka. IBLims

Sawono, Jonatan. 2013. Model Model Linier dan non linier dalam IMB SPSS 21 untuk riset. Jakarta: Elex Media Komputindo

Sudarsono. 2010. Pustakawan, Cinta dan Teknologi. ISSN: 9786029585803. Jakarta:ISIPII

Tim LPPM, STIKI. 2014. Panduan Hibah Penelitian Pengembangan Dosen STIKI. Denpasar: STIKI copyright

Widodo. 2015. Implementasi Teknologi Informasi di Perpustakaan. IBLims, BPSDM KP 